\title{
Using Student Response System to Enhance Listening and Speaking Skills for EFL Saudi Secondary School Students
}

\author{
Omar Abdullah Amin \\ Dr.Aly A. Qoura
}

Professor of curriculum \&Instruction: TEFL Faculty of Education

Mansoura University

\section{Dr.Adel A. AlSheikh}

Professor of Curriculum\& Instruction (TEFL), Faculty of Education Mansoura University

\section{Abstract:}

This study was conducted to investigate the
effectiveness of using student response system to
develop EFL listening and speaking skills for secondary school students. Participants of the study were sixty students from al Taleah secondary school and were divided into control group and experimental one. Instruments of the study were a pre-post listening and speaking skills test to determine the level of the student listening and speaking skills. After measuring its validity and reliability, the listening and speaking skills test was administrated on both groups. Results showed no statistically significant differences between the two groups.

While teaching the control group with traditional ways, the researcher administrated the proposed SRS-based program on the experimental group. Finally, post-listening and speaking test was administered on both groups. Results showed that experimental group performed better in the post- listening and speaking test after the experiment. This showed that the treatment program has an effective impact on improving EFL students' listening and speaking skills. According to all of that, it could be concluded that using SRS to develop EFL listening and speaking skills for EFL students is very effective.

Key words: student response system (SRS), clickers, listening and speaking.

\section{Introduction:}

English is an important language in the world. It has become the international language of communication (Seidlhofer, 2005) "Of the 4,000 to 5,000 living languages, 
English is by far the most widely used" (Broughton et al., 1978, p.1). It is considered the first language in many countries such as the United States of America, the United Kingdom and Australia. In other countries, English is considered a second or foreign language. In the Kingdom of Saudi Arabia, where the present study takes place, English is regarded as a foreign language and is generally treated as an academic subject in schools. In most cases, English is not the medium of teaching and learning, and is not widely used outside the classroom. Most English teachers concentrate on improving reading and writing skills and do not take into account the importance of speaking and listening skills. In other words, teaching the oral skills in Saudi schools is mostly ignored.

A paradigm shift is described by Shaw (2009) as occurring in today's educational system. Education is moving away from 20th century teaching methods that include direct instruction, memorization, textbooks, and passive learning toward learning that is collaborative, interactive, interdisciplinary, global and real-world project-based. She believes knowledge is not memorization of facts and figures, but is constructed through research and the application of what is learned. According to Shaw, today's schools should incorporate the 21st century skills that include higher order thinking skills, multiple intelligences, synthesis, analysis, and evaluation. Technology is becoming the means through which these 21st century skills are being achieved as online instruction and assessments, interactive whiteboards, blogs, SRS, podcasts, and Web Quests are being integrated into the curriculum to more fully engage learners. Shaw (2009).

The present studies use clickers as a tool for student response system. Clickers are famous instrument which are used to enhance students' engagement in the class room. The i>clicker is an interactive classroom response system allowing educators to poll students in class, view the results immediately, and then provide feedback. This can be used with other programs, like 
PowerPoint, for asking prepared questions, or used by itself for impromptu questions.

\section{Review of Literature:}

This part mentions the existing information about the study's variables "SRS", "listening" and "speaking"

\section{Student Response System}

The Student Response System (SRS) is one of the productive alternative pedagogies that educators can access to ensure learners' engagement in critical thinking and active participation during instructional processes (Crouch \& Mazur, 2001; Mintzes \& Leonard, 2006). The SRS is a wireless interactive handset that collates and projects students' (anonymous) responses to a teacher's questions. A receiver (dongle) attached to the Universal Serial Bus (USB) of the teacher's computer recognizes and captures students' responses from the individual handsets. The recorded data are automatically displayed on the projection screen. The class can then discuss and possible reattempt the questions (M. Johnson \& Robson, 2008; Marlow, Wash, Chapman, \& Dale, 2009; Surgenor, 2010).

\section{Student response system and language learning}

To effectively prompt interaction and peer instruction in the classroom through SRS, Fagen, Crouch, and Mazur (2002) and K. Johnson and Lillis (2010) suggest that:

- At the beginning, during or at the end of the lesson, the teacher displays pre-prepared PowerPoint slide question(s)

- Students respond through the wireless SRS keypads

- Teacher prompts group interaction or peer discussion after the display of responses with no clue to the correct answer

- Students respond a second time through the keypads

- Correct answers are indicated, followed by the teacher's explanation, comments and contributions. 
Adopting SRS in the classroom provides teachers with the opportunity to measure learners' prior knowledge, determine whether students have completed assigned reading, test students' conceptual understanding, and facilitate class or peer discussion (Lea, 2008). Cain and Robinson (2008) assert that the integration of SRS in instructional processes fosters a higher level of interaction. Similarly, Hoffman and Goodwin (2006) and Martyn (2007) emphasize that the use of SRS triggers increased interaction in the classroom. The "game approach" features of SRS technology and the fun it adds to the instructional process also enhance the creation of an enabling learning environment. According to Wood (2004), an easy way of measuring students' understanding and learning needs is through the teacher's use of SRS. Bergtrom (2006: p. 106) summarized the pedagogical advantages of student response systems as:

- Increased learners' participation

- Better formative assessment of students' learning

- Instant feedback on students' retention and learning to both students and instructors

- Involving all students in critical thinking exercises

- Increased opportunities for student-student interaction

- Increased opportunity for student-lecturer interaction in the class

- Increased student attention and awareness in the class

- More lively engagement of students

- Improved attendance

\section{Student Response Systems and Pedagogy}

A lot of indication from the learning and psychological literature suggests that giving extra exercises and immediate feedback improves the learning course (e.g., Kuh et al. 1994). Recent Studies state that outside provided feedback allows learners to be more active (Kulhavy and Stock 1989). Butler and Winne (1995) suggest that reducing the time-based spacing between the presented exercises and feedback may encourage a 
deeper processing of the material by controlling the cognitive activities needed to study efficiently. Giving students chances to answer questions and obtain immediate feedback on their replies also gives them control over their own learning, which, facilitates understanding (Locke and Latham 1990).

The facility of instant feedback done by SRS technology signifies a substantial advantage in light of the restrictions that teachers may otherwise face. Teachers naturally offer experience to exercise questions through study directors that are frequently involved with the textbook. Aside from the inquiry of whether students really use these guides, one restriction of this plan is that an important amount of time must pass between the presentation of a material in class and the student's assessment of the exercise questions. Likewise, feedback in the classroom is typically given by a graded exam or quiz that is refunded sometime after the test is accomplished, lost the chance to current instant feedback in a way that would let students to involve in a deeper procedure of information construction (Butler and Winne 1995). SRS gives a technical resolution to this pedagogical problem.

\section{What is the Clicker?}

Clickers are the handheld devices used in a SRS, commonly called "clickers" or "key-pads" in the United States and "handsets" or "zappers" in the United Kingdom (d'Inverno, 2003; Simpson \& Oliver, 2006). Clickers (figure 1) are small transmitters about the size of a television remote control. Students use their clickers to transmit their answers by pressing the clicker buttons. Clickers use either infrared or radio frequency technology to transmit and record student responses to questions. The technology allows for the active participation by all students and provides immediate feedback to the teachers and the students regarding any confusion or misunderstandings of the material being presented. 

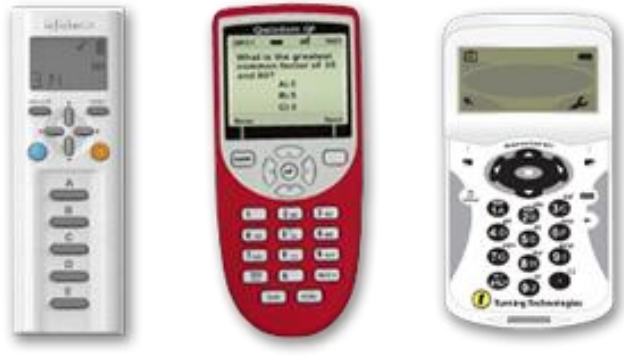

Figure (1) (the clickers)

\section{Benefits of Using Clickers}

In recent eras, university instructors have investigated with numerous substitutions to the old-style instructional model of teaching, and assumed methods of learning that make students more engaged and active during class. Clickers system have been utilized to motivate student learning particularly in arithmetic classes (Liu \& Stengel, 2011). The main advantage of clickers is that learners can take part and reply to questions anonymously, teachers can gather learning outcomes immediately and teachers follow the philosophies of game-based learning in the 21st century.

First, anonymous responses to questions add more value to learning than traditional techniques such as calling on individual students or even asking students to designate a response by a show of hands. In mathematics classes, many students are hesitant to respond to an answer until they know how others will respond. With clickers, the fear of embarrassment that the student's answer may be wrong is mitigated as the answer is submitted anonymously. Students can freely express their views in complete anonymity and the cumulative view of the class appears on a public screen. Clickers allow students to respond to questions in a safe manner thereby encouraging them to take additional risks with their potential responses. As a result, teachers receive greater student engagement, increased student interest and heightened discussion and interactivity in mathematics classrooms. 
Second, clicker technology doesn't just enhance active learning but it offers immediate feedback for both teachers and students. Teachers can rapidly look at what responses students have chosen, and instantly gauge their level of comprehension. In contrast, in the traditional classroom environment, the teacher would need to instruct the students to "put your right hand for A, left hand for B, both hands for C, and stand up for D" to simulate what the clickers achieves anonymously and instantly.

Third, fitting clickers in the classroom also benefits fulfill the requirements for 21st century learning. Students in the 21st century have grown up using computer and video games for learning and entertainment. Consequently, many of these students are more likely to reply to questions using clickers instead of traditional classroom methods such as raising a hand (Martyn, 2007).

\section{Listening skills}

According to Vandergrift (1999), listening understanding is a compound process in which listeners carry out an active role in telling the difference between sounds, acquiring vocabulary and grammatical structures, understanding sound and stress, and finally, making use of all the skills talked about/said above, explaining the statement within the (related to how people and cultures interact) big picture. Listening skills are anything but easy to master. For many ESL/EFL learners, listening is the thing they feel most frustrated with. On the one hand, they can't control the speed of speech and they tend to have problems in changing code into understandable language sounds that don't occur in their mother tongue. Reduced English sounds (lazy speech) or contractions are two examples. On the other hand, even when they hear sounds properly, mostly they have understanding problems because of lacking vocabulary.

\section{Importance of Listening}

Listening is considered the utmost important part of interaction because it is essential in giving a considerable and meaningful response. Especially in learning a language for 
communicative purpose, listening plays a vital role, as it supports the language learner to acquire pronunciation, word stress, vocabulary, and syntax and the comprehension of messages conveyed can be based solely on tone of voice, pitch and accent; and it is only possible when we listen. Without understanding input appropriately, learning simply cannot get any improvement. In addition, without listening skill, no communication can be achieved

Listening is the principal skill created; it precedes the other three main skills (Coakley,1988). Likewise, listening is the utmost every now and again utilized skill (Scarcella\&Oxford,1992). As indicated by (Devine,1982:74) it is the essential way by that approaching thoughts and data are acquired. Gladney (1980) investigated a study which affirmed the supremacy of listening besides demonstrated that the segment of spoken correspondence time consumed by English understudies was 52.5 percent in listening, 17.3 percent in reading, 16.3 percent in speaking, and 13.9 percent in writing. Wolvin and Coakley (1988) presumed that listening expends a greater amount of day by day correspondence time than different types of verbal correspondence in the classroom.

\section{The Role of Listening in Language Learning and Acquisition:}

"Today, the centrality of listening in language learning is well established" (Morley, 2001). Research has demonstrated that of the four language skills, listening is possibly the utmost important for language acquiring, particularly for beginners. It is the initial language approach that beginners get. It offers a basis for all language aspects and mental growth, and it carries out a main role in the developments of learning and interaction. Accordingly, listening ought to be a main part of concern to foreign language educators and learners as well (Hyslop\& Tone, 1988; Lund, 1990; Feyten, 1991;).

Listening is an essential language skill that naturally increased faster than speaking and that effects the progress of 
reading and writing capability in the foreign language. Rost, 1990; Feyten, 1991; Oxford, 1993; Mendelsohn and Rubin, 1995; Vandergrift, 1997 stated that listening is an extremely integrative skill which has a crucial role in language acquiring.

\section{Teaching Listening}

Listening skills are crucial for your learners. listening is the most frequently used skill of all four skills. Listening and speaking are frequently taught at the same time, but beginners, supposed to be taught more listening than speaking training. It's vital to speak as close to natural speed as possible, although with beginners some slowing is typically needed (www.nclrc.org/essentials/listening/liindex.htm). Teachers are able to make students learn fast without reducing their speaking speed by using simplified vocabulary, using smaller sentences and using more long pauses in their speech.

listening activities which don't need students to respond in spoken language are easier than those that do. Students can respond physically to a command, choose a suitable story or object, circle the correct answer or words on a test, draw a direction on a map, or finish a diagram as they listen. The difficult activities such as repeating what they heard, translating a listening passage into their native language, taking notes, making a draft, or reply to comprehension questions may follow the easier activities. To add more challenge to the activities, students can be asked to continue a story text based on what they heard, solve a specific problem, make a roe play or participate in real-time conversation.

\section{Kinds of Listening}

\section{a. Intensive listening}

According to Harmer (2002: 130) intensive listening is the live listening, in this kind of listening, teacher talks to the students directly. Some examples of the live listening are: 


\section{Reading aloud}

Reading aloud is a pleasant activity, when done with conviction and style, the teacher reads aloud to a class and by this way students are allowed to hear a clear spoken version of written text. Teachers can make this activity more enjoyable if the teacher is arranged to make a big thing of it. The teacher may act out dialogues either by playing two parts or by inviting a colleague into the classroom.

\section{Storytelling}

Teachers are preferably placed to tell stories which, in turn give outstanding listening material. Students can be asked to guess what is happening after in the story or they can give description to characters of the story or say comment on it in some other way.

\section{Interviews}

Interview is a motivating listening activity, especially when students themselves make up the questions. In such condition, students are keen on listening for answers to their question, rather than implementing other people's questions. Teachers may ask strangers visit the class to be interviewed by the students, teachers or students can also be the subject of interviews themselves.

\section{Conversation}

This kind of activities can be done by inviting colleagues to come to class. Teachers can make conversations with them about English or some related subject. By this way, students have the chance to watch the interaction as well as listen to it. We can also extend storytelling possibilities by role playing.

\section{b. Extensive listening}

Extensive listening is kind of listening activities which required more general free practices for some statement, and it doesn't need specific instruction or guiding. These kinds of listening aim at: 
1. Remind the materials what was known through new method.

2. Given opportunity to the students to hear and listens the new vocabulary and structure.

The supplies of extensive listening usually happen outside the classroom, in the students' home, made by the teachers' car or personal stereos as they travel from one place to another place. There are four kinds of extensive listening which are:

\section{a. Social listening}

This is usually taking place in the public places, where are people speaking to each other spontaneously about the daily life interesting topic.

\section{b. Secondary listening}

It is kind of unplanned listening activity. For example: driving by listening music

\section{c. Aesthetic listening or appreciation listening}

It is the end level of unplanned listening from listening music until in the level of enjoying the music.

\section{d. Passive listening}

It refers to understanding some of listening materials without unconscious efforts such as listening to language lesson while jogging.

\section{Speaking skill}

Teaching English as a foreign language (TEFL) needs to expose the learners to which's known as the foreign language skills: reading, speaking, writing and listening. The primary and also the final target of exploit these language skills is to realize an acceptable improvement of skills of getting and manufacturing the foreign language either in spoken or written type, i.e. succeeding in a decent mastery within the creative and receptive skills.

Speaking thought to be the foremost ability to be developed as a result of its importance for demonstrating being 
proficient

in

a

foreign

language,

Students will be placed in situation wherever communicating in English is required, that's the reason of focusing on speaking specially. It is also defined as an activity in which the speaker produces utterances to express his/ her ideas in order to exchange information, so the listener understands what the speaker means.

\section{Importance of Speaking}

The Importance of Teaching Speaking is a crucial part of foreign language learning. The main goal of teaching speaking should improve students' communicative skills, because by that way, learners are able to express themselves and know how to follow the communal and cultural rules suitable in each communicative condition. communication happens, where there is dialogue. Without speech, we are not able to communicate with one another. The importance of speaking skills hence is huge for the learners of any language. Without speech, language is condensed to a simple writing.

Thornbury (2005: 1) explains that since ages it was supposed that the capability to speak fluently was a result of teaching grammar and vocabulary, with a bit of pronunciation thrown in. yet, it was proved that speaking is much more compound than this and that involves both command of certain skills and several different types of knowledge.

Richards (2008: 19) states that being proficient in speaking in a foreign language is considered a priority for foreign language learners. Accordingly, they usually assess their achievement in language acquisition based on the degree of their satisfaction on their fluency and accuracy during speaking in a foreign language.

\section{Components of the Speaking Skill}

According to Syakur (1987: 5), speaking is a complex skill because at least it is concerned with components of grammar, vocabulary, pronunciation, and fluency: 


\section{a) Grammar}

Grammar is needed for students to arrange a correct sentence in conversation. It is in line with explanation suggested by Heaton (1978: 5) that student's ability to manipulate structure and to distinguish appropriate grammatical form in appropriate one. The utility of grammar is also to learn the correct way to gain expertise in a language in oral and written form.

\section{b) Vocabulary}

Vocabulary means the appropriate diction which is used in communication. Without having a sufficient vocabulary, one cannot communicate effectively or express their ideas in both oral and written form. Having limited vocabulary is also a barrier that precludes learners from learning a language. Therefore, language teachers should process considerable knowledge on how to manage an interesting classroom so that the learners can gain a great success in their vocabulary learning. Without grammar, very little can be conveyed and without vocabulary nothing can be conveyed.

\section{c) Pronunciation}

Pronunciation is the way for students to produce clearer language when they speak. It deals with the phonological process that refers to the components of a grammar made up of the elements and principles that determine how sounds vary and pattern in a language. There are two features of pronunciation; segmental and supra segmental features. A speaker who constantly mispronounces a range of phonemes can be extremely difficult for a speaker from another language community to understand (Gerard, 2000:11).

\section{d) Fluency}

Fluency in speaking is the aim of many language learners. Signs of fluency include a reasonably fast speed of speaking and only a small number of pauses and "ums" or "ers". These signs indicate that the speaker does not have to spend a lot of time searching for the language items needed to express the message 
(Brown, 1994). Fluency may be defined as the ability to get across communicative intent without too much hesitation and too many pauses to cause barriers or a breakdown in communication (Crystal, 1977; Byrne, 1986; Nation, 1991). Speaking fluency is 'the ability to link units of speech together with facility and without strain or inappropriate slowness or undue hesitation' (Hedge, 2000).

\section{Micro skills and Macro skills of Speaking}

Speaking English routinely and fluently is very difficult for many non-native speaker people, especially students. To be able to interact well, a speaker has to master two skills in speaking. They are micro skills and macro skills. A list of 16 micro skills in speaking was done by Brown (2001: 272). They are:

1. Produce amounts of language of changed lengths.

2. Verbally make differences among the English phonemes and allophonic alternatives.

3. Use English stress patterns, words in stressed and unstressed locations, periodic construction, and intonational contours well.

4. make word and phrase reduction forms.

5. Use a satisfactory number of words to complete practical purposes.

6. Give fluent speech at different rates.

7. Display spoken production and use various strategic policies - pauses, filters and self-corrections to enhance the clarity of the message.

8. utilize structural word classes (nouns, verbs, etc.), system (e.g., tense, agreement, pluralization), word order, patterns, rules, and elliptical forms.

9. create natural elements in speech.

10. Provide a specific meaning in different grammatical forms.

11. Use cohesive devices in spoken discourse.

12. Complete suitably communicative purposes to situations, participants, and goals. 
13. Utilize appropriate records, realistic resolutions, and other sociolinguistic features in face-to-face conversations.

14. Send links and connections between events and communicate such relations as main idea, supporting idea, new information, given information, generalization, and exemplification.

\section{Assessing Speaking}

Brown (2003: 167-176) suggests assessment tasks for interactive speaking (interpersonal and transactional):

\section{1) Interview}

"oral production assessment" is usually defined as an oral interview: a person who asks and another person responds sit down face-to-face exchange and progress through an etiquette of inquiries and commands. Interview time varies in length from five to forty-five minutes, depending on the purpose and context.

\section{2) Drama, simulations and role-plays:}

These second kind of assessment is an important part of assessing speaking. According to Bygate (1987), they are not done for viewers; the learners work in pairs or in groups within an unreal setting. O'Malley and Pierce (1996) states that activities depend on drama, simulation and role play are more reliable because they offer a presentation for using the real-life conversation like "repetitions, interruptions, recitations, facial expressions and gestures." Students often involve in fake character in role-plays, drama and simulations activities, where their worry is vanished, enthusiasm is improved and their language achievement becomes greater.

\section{3) Discussion and Conversation}

After a content-based lesson, a discussion can be carried out for numerous motives. The students may need to make a conclusion, share ideas about an occasion, or come up with explanations in their discussion groups. Before the discussion, it is crucial that the objective of the discussion activity is set by the teacher or by students themselves to make it easy to achieve the 
target goal. In this way, the discussion points are relevant to this purpose, so that students do not spend their time chatting with each other about irrelevant things (Kayi, 2006).

\section{4) Games}

Among informal assessment devices are a variety of games that directly involve language production.

\section{5) Story completion:}

This is an enjoyable, whole-class, free-speaking activities valid for high level students. In such activities students sit in a circle and a teacher starts to tell a story, but after a few sentences the teacher stops narrating. Then, each student starts to complete the story from the point where the previous one stopped. Each student is supposed to add from four to ten sentences. The completion of the students is totally from their imagination. Students can add new characters, events, descriptions and so on.

\section{Related Studies:}

\section{Studies related to developing speaking skills}

The following studies are reviewed by the researcher and they are related to the approaches and trends used to develop speaking skills;

Fabio(2015) conducted a study to investigate about how students' speaking skills may be enhanced through the employment of drama techniques. In order to achieve these goals two groups of participants had been selected to conduct the study: a control group, and the research group, both of them composed by the second-year university students. Before starting the investigation, the experimental group students have been administered pre-questionnaires to measure their initial level of motivation. Both groups were also tested to evaluate their speaking skills level. In continuation, the research group followed the learner-centred teaching syllabus based on drama activities, meanwhile the control group continued with their daily routine. At the end of the experiment the research group 
was administered a post-questionnaire to check their level of motivation and both groups were tested again to measure the development of their speaking skills the data analysis reveal that the investigation group's motivation has been enhanced, as well as their speaking level: despite the limited time of research, the respondents recorded higher outcomes compared to the control group.

Abd Elrahman (2013) examined the effect of using shared online oral diaries on the EFL Saudi First year university students' speaking proficiency. It used one male and one female EFL Saudi First year university student's classroom sections to represent the experimental group and one male and one female classroom sections to represent the control group. An equivalent speaking proficiency test, developed by the researcher, was applied on the control and the experimental groups before the study started to ensure their equivalence; and was also used as a post-test. The results of the post-test revealed significant differences between the mean scores of the experimental group and the mean scores of the control group in favor of the experimental group.

\section{Studies related to developing listening skills}

Arono (2014) conducted a study to know the students' activities in learning critical listening by using interactive multimedia and to measure the effectiveness of that multimedia in improving students' critical listening ability. The tools were test, observation, and interview. The results of the research were (1) the students created active, creative, and effective learning process independently in measuring and developing each step of listening learning model. (2) Interactive multimedia was effective learning media to improve students' critical listening skill (3) Critical listening strategy performance in PMAI Model could improve students' critical listening ability so that this model is better to be applied as an implementation of reference in listening learning model. (4) Learning media with interactive multimedia can improve students' critical listening skill than 
audio learning media because listening is not only aural aspect but also visual aspect

Suryani (2012) examined varied listening tasks conducted at the language laboratory to improve students' listening skills The three research questions addressed were what are the action plans conducted by the researcher? how does the researcher use varied listening tasks in the language laboratory?, and how do the students' listening skills improve? Three instruments were used in the study namely a questionnaire, pretest and post- test, and observation. The data obtained from the questionnaire and pre-test and post- test were analyzed quantitatively and qualitatively, using descriptive and inferential analyses. The result of this study reveals three findings. First, the action plans of the study. Second, the process of the use of varied listening tasks in the language laboratory. Third, the students' five listening skills.

\section{Studies related to student response system}

\section{The Impact of SRS on Achievement}

A study by Thomas, Blood Pinter, Carlisle and Goran(2015) presents findings from an investigation of student response systems (SRS) in an undergraduate pre service teacher education classroom to investigate the impact of SRS use during lecture on the topic of learning disabilities (LDs). Participants were randomly assigned to the SRS group, a written response group, or a no response group, and evaluated at pre- and posttest for content knowledge, during lecture for reading accountability and engagement, at posttest regarding satisfaction with the learning experience, and following lecture, participants were asked to respond to a case study of a student with LD. Findings indicated that all participants performed significantly better at posttest on the measure of content knowledge, with no significant differences between groups. On the during lecture measure of engagement, students in the written response group outperformed peers in the SRS group on reading accountability items, but students in the SRS group demonstrated significantly 
better understanding of content and reported higher efficacy for their learning in comparison with peers. Participants were satisfied with the learning experience created by SRS use and reported that it improved their accountability for reading, increased their engagement with content, and that given a choice, they would prefer to use SRS in future classes.

Klein (2013) tried to make a model for successful use of student response systems. The study presented a model developed to assist teachers in selecting, implementing, and assessing student response system (SRS) use in the classroom. The study depended on best practices described in the literature and several years of SRS use in a traditional higher education classroom setting. Research indicated that SRS technology is effective in achieving desired outcomes in higher education settings. Studies indicate that effective SRS use promotes greater achievement of learning outcomes, increased student attention, improved class participation, and active engagement. Results also showed that student feedback indicates increased class participation and engagement with SRS technology. Teacher feedback indicates opportunities for contingent teaching.

\section{The Impact of SRS on learning and student engagement:}

The research regarding technology and its impact on attitudes toward learning and student engagement has become more extensive in recent years as well. It has been demonstrated, for example, that the use of interactive whiteboards in U.S. classrooms is a promising approach for engaging students who have grown up on the Web Larson (2009) found that the use of online learning communities in a fifth-grade classroom to discuss and share opinions about literature was very effective. Students who were typically shy or struggling readers in traditional literature circles were less hesitant to share their ideas in the online group setting.

Research has also been conducted on the impact of SRS on student participation, engagement, and attitudes toward learning 
in the classroom. Because SRS are often used for formative and self-assessment purposes, it is important to note the connections between such assessment methods and student engagement, attitudes (efficacy), and participation in the classroom.

A 2008 study by Brookhart, Moss and Long, concluded effective teachers create situations that maximize student learning potential, specifically by providing students and teachers with regular feedback on how well students understand key concepts and skills. The authors argue formative assessment: empowers students; makes teachers more effective; and restores students' natural love of learning. As this assessment is nonjudgmental in approach, students are more likely to think for themselves and to openly share their understandings. According to Brookhart, Moss, and Long, students become "the driving force in their own learning". It appears SRS can become an important tool in fostering student engagement through formative and selfassessment methods.

\section{The Impact of SRS on ESL learning outcomes:}

Agbatogun, A (2012) noted that use of, the traditional lecture method deprives students of the necessary interaction, active engagement and dialogic communication that could promote improved learning outcomes. He investigates the effectiveness of SRS in English language classrooms with a view to improving the listening and speaking of learners. In essence, this study was a quasi-experimental design conducted within 11 weeks, to compare the listening and speaking of pupils exposed to SRS and those taught in the traditional classroom. 67 pupils from two primary schools constituted the sample of the study.

Language Listening Tests and English Language Speaking Tests were used for data collection. While significant difference was found between the pre- and post-tests of the SRS group, no such significant difference was found within the control group. The results further show that the SRS group outperformed the control group at the post-test stage. Pupils' listening and speaking positively and significantly correlated with the listening and speaking skills of pupils in the SRS group. Speaking skill was 
also found to be potent predictor of pupils' listening and speaking in the SRS group. Agbatogun, (2012) Enhancing Second Language Skills Development Using Students Response System. Alaba examines L2 learners' development of language skills based on the use of personal response system, communicative approach and the traditional lecture method in the ESL classroom. He finds a significant difference between the pre-test and post-test language skills development scores of pupils in the experimental group.

\section{The Problem of the Study:}

In order to investigate the level of EFL listening and speaking skills for students, the researcher conducted a pilot study in which the students were requested to answer the listening and speaking test. Results of the pilot study showed that those students suffer from a lack in their listening and speaking skills which were required for those students. Therefore, there was a need to investigate this problem.

\section{The Problem of the Study:}

In order to investigate the level of EFL listening and speaking skills for secondary school students, the researcher conducted a pilot study in which the students were requested to answer the listening and speaking test. Results of the pilot study showed that those students suffer from a lack in their listening and speaking skills which were required for those students. Therefore, there was a need to investigate this problem.

\section{Problem Statement:}

Despite the great importance of listening and speaking for EFL students, there is a noticeable lack of it among them, so there is a need for a study to try to remedy this lack and bridge the gap in students' education. Therefore, the researcher finds it is important to set up a program based on student response system to enhance listening and speaking or EFL secondary school students. 


\section{Research Questions:}

The problem of the study will be explored through answering the following main question:

Can Student Response System (SRS) contribute to enhancing Saudi secondary stage students' listening and speaking skills?

The main question leads to the following sub questions:

1. What is the current level of listening and speaking skills of EFL third year secondary students?

2. What is the proposed SRS program for enhancing the listening and speaking skills of EFL third year secondary school students?

3. To what extent is the proposed training program effective in developing EFL third year secondary stage students' listening and speaking skills?

\section{Hypotheses of the Study:}

The study verified the following hypotheses:

1. There is a statistically significant difference at 0.05 level between the mean score of the experimental group and control group in the listening skills on their performance of the post-test in favor of the experimental group.

2. There is a statistically significant difference at 0.05 level between the mean score of the experimental group and control group in the speaking skills on their performance of the post-test in favor of the experimental group

3. There is a statistically significant difference at 0.05 level between the mean scores of the experimental group in the listening skills on the pre-and the posttest in favor of the post test.

4. There is a statistically significant difference at 0.05 level between the mean scores of the experimental group in the speaking skills on the pre-and the posttest in favor of the post test. 


\section{Purpose of the Study:}

The present study aimed at:

1. Determining the current level of listening and speaking skills of EFL third year secondary stage students

2. Identifying the features of the proposed (SRS) training program for improving the listening and speaking skills of EFL third year secondary stage students.

3. Measuring the effectiveness of the proposed training program by using student response system in enhancing Saudi secondary stage listening and speaking skills.

\section{Delimitations of the Study:}

The present study was delimited to:

1. Some listening and speaking skills which EFL third year secondary stage Saudi students should acquire by the end of the training program which is based on (SRS).

2. A sample of EFL third year secondary stage Saudi students at Al Taleah secondary school, east educational office, department of education in Jeddah

\section{Research design:}

The researcher used the quasi experimental design using two groups: the experimental group and the control group. The experimental group was taught through student response system while the control one was taught through the traditional way in the class. Both groups received the pre and post - administration of the listening and speaking skills test.

\section{Participants and Setting of the Study:}

\section{Participants}

The sample of the present study contained 60 EFL Saudi third year secondary school students. They were divided into two groups; the first group (the control group) will take listening and speaking classes in the ordinary classroom and the second group (the experimental group) will be enrolled in listening and speaking classes using clickers. 


\section{Instruments of the study:}

The following instruments were used in order to fulfill the purpose of the study:

1. A pre-post listening test for measuring students' listening skills.

2. a pre-post speaking test for measuring students' speaking skills.

3. a scoring rubric for speaking skills test

\section{Results and discussions:}

For the purpose of testing the study hypotheses, the researcher used the difference between students' scores before and after applying the test. Also, different statistical methods were employed through using the SPSS for handling the results, T-test value to show the results of the collected data. Results are shown in the following tables:

Table (1):T-test for the post test score of the experimental and the control group in the listening and speaking sub-skills and the total score.

\begin{tabular}{|c|c|c|c|c|c|c|}
\hline \multirow[b]{2}{*}{ Skill } & \multirow[b]{2}{*}{ Groups } & \multirow[b]{2}{*}{ Test } & \multirow[b]{2}{*}{ Mean } & \multirow[b]{2}{*}{ SD } & \multicolumn{2}{|c|}{ Paired T- test } \\
\hline & & & & & $T$ & $\begin{array}{c}\text { P - } \\
\text { value }\end{array}$ \\
\hline \multirow{4}{*}{$\begin{array}{c}\text { Listening } \\
\text { for specific } \\
\text { information }\end{array}$} & \multirow[t]{2}{*}{ control } & Pre & 1.97 & .81 & \multirow{2}{*}{.305} & \multirow{2}{*}{.762} \\
\hline & & Post & 2.53 & .78 & & \\
\hline & \multirow{2}{*}{ Experimental } & Pre & 1.90 & .88 & \multirow{2}{*}{6.75} & \multirow{2}{*}{0.001} \\
\hline & & Post & 3.93 & .83 & & \\
\hline \multirow{4}{*}{$\begin{array}{l}\text { Listening } \\
\text { for gist }\end{array}$} & \multirow{2}{*}{ control } & Pre & 1.90 & .76 & \multirow{2}{*}{1.27} & \multirow{2}{*}{.206} \\
\hline & & Post & 2.37 & .89 & & \\
\hline & \multirow[b]{2}{*}{ experimental } & Pre & 1.60 & 1.03 & \multirow{2}{*}{8.11} & \multirow{2}{*}{0.001} \\
\hline & & Post & 4.10 & .76 & & \\
\hline \multirow{4}{*}{$\begin{array}{l}\text { Listening } \\
\text { for details }\end{array}$} & \multirow{2}{*}{ control } & Pre & 1.97 & .80 & \multirow{2}{*}{.305} & \multirow{2}{*}{.762} \\
\hline & & Post & 2.53 & .89 & & \\
\hline & \multirow[b]{2}{*}{ experimental } & Pre & 1.90 & .88 & \multirow{2}{*}{6.075} & \multirow{2}{*}{0.001} \\
\hline & & Post & 3.97 & .93 & & \\
\hline \multirow{4}{*}{ Total } & \multirow[t]{2}{*}{ control } & Pre & 5.83 & 1.93 & \multirow{2}{*}{.785} & \multirow{2}{*}{.436} \\
\hline & & Post & 7.43 & 1.74 & & \\
\hline & \multirow{2}{*}{ experime } & Pre & 5.40 & 2.33 & \multirow{2}{*}{9.30} & \multirow{2}{*}{0.001} \\
\hline & & Post & 12.00 & 2.05 & & \\
\hline
\end{tabular}


Results in table one indicate that the mean score of the students of each listening sub-skill in the experimental post-test was higher than the students' mean score in the control group post-test application. Also, the table shows that the students' mean score in the overall post-listening test in the experimental group was (12.00) and the control group overall score in the post-test was (5.40). These results indicate that the higher mean score is the score of the experimental group post-test which is also higher than the control group's mean score.

The paired T-test results indicate that the differences between the mean scores of the students in the post-listening test in the control and experimental group were statistically significant at $<0.001^{*}$ level in favor of the post application of the SRS training in the experimental group

The variance between the experimental and the control group according to mean scores and t-test values lead to accepting the first hypotheses of the present study. The increase in the students' level in the experimental group can be Interpreted that students in the experimental group were active and motivated in using SRS. The active nature of SRS led to this increase and this difference. The students has the opportunity to get better formative assessment, instant feedback, involving in critical thinking exercises,

more interaction, lively engagement of students and improved attendance

Students in the control group learned through the regular way. On the contrary, students in the experimental group were more active, faster and intelligent in learning through the SRS.

Results in table two indicate that the mean score of the students of each speaking sub-skill in the experimental post-test was higher than the students' mean score in the control group post-test application. Also, the table shows that the students mean score in the overall post-speaking test in the experimental group was (33.40) and the control group overall score in the post-test was (25.17). These results indicate that the higher 
mean score is the score of the experimental group post-test which is also higher than the control group's mean score.

Table (2):T-test for the post test score of the experimental and the control group in the speaking sub-skills and the total score.

\begin{tabular}{|c|c|c|c|c|c|c|}
\hline \multirow[b]{2}{*}{ Skill } & \multirow[b]{2}{*}{ Groups } & \multirow[b]{2}{*}{ Test } & \multirow[b]{2}{*}{ Mean } & \multirow[b]{2}{*}{ SD } & \multicolumn{2}{|c|}{ Paired T-test } \\
\hline & & & & & $\mathbf{T}$ & $\begin{array}{c}P \text { P - } \\
\text { value }\end{array}$ \\
\hline \multirow{4}{*}{ pronunciation } & \multirow[t]{2}{*}{ Control } & pre & 4.50 & 1.73 & \multirow{2}{*}{.239} & \multirow{2}{*}{.812} \\
\hline & & post & 5.03 & 1.54 & & \\
\hline & \multirow[t]{2}{*}{ Experimental } & pre & 4.40 & 1.49 & \multirow{2}{*}{4.63} & \multirow{2}{*}{0.001} \\
\hline & & post & 6.73 & 1.28 & & \\
\hline \multirow{4}{*}{ fluency } & \multirow{2}{*}{ Control } & pre & 4.77 & 1.19 & \multirow{2}{*}{.506} & \multirow{2}{*}{.615} \\
\hline & & post & 5.23 & 1.04 & & \\
\hline & \multirow[b]{2}{*}{ experimental } & pre & 4.60 & 1.35 & \multirow{2}{*}{5.86} & \multirow{2}{*}{0.001} \\
\hline & & post & 6.93 & 1.20 & & \\
\hline \multirow{4}{*}{ vocabulary } & \multirow[t]{2}{*}{ Control } & pre & 4.47 & 1.30 & \multirow{2}{*}{.187} & \multirow{2}{*}{.853} \\
\hline & & post & 5.10 & 1.24 & & \\
\hline & \multirow[b]{2}{*}{ experimental } & pre & 4.53 & 1.46 & \multirow{2}{*}{4.71} & \multirow{2}{*}{0.001} \\
\hline & & post & 6.60 & 1.22 & & \\
\hline \multirow{4}{*}{ Accuracy } & \multirow{2}{*}{ Control } & pre & 4.37 & 1.38 & \multirow{2}{*}{.513} & \multirow{2}{*}{.610} \\
\hline & & post & 4.90 & 1.40 & & \\
\hline & \multirow{2}{*}{ experimental } & pre & 4.57 & 1.63 & \multirow{2}{*}{4.55} & 0001 \\
\hline & & post & 6.53 & 1.38 & & 0.001 \\
\hline & Contuol $>$ & Pre & 4.47 & 1.52 & 000 & 026 \\
\hline Compress & Contror & post & 4.90 & 1.56 & .080 & .936 \\
\hline & experimental & pre & 4.50 & 1.69 & 4.54 & 0001 \\
\hline & & post & 6.60 & 1.32 & 4.54 & 0.001 \\
\hline & Control & pre & 22.57 & 5.58 & 021 & 983 \\
\hline Total & & post & 25.17 & 5.55 & & \\
\hline 10tal & experimental & pre & 22.60 & 6.42 & 507 & 0001 \\
\hline & & post & 33.40 & 5.12 & (0.3) & 0.001 \\
\hline
\end{tabular}

The paired T-test results indicate that the differences between the mean scores of the students in the post-speaking test in the control and experimental group were statistically significant at $<0.001^{*}$ level in favor of the post application of the SRS training in the experimental group. 
Table (3):T-test of the experimental group on the pre-post administration of the listening test

\begin{tabular}{|c|c|c|c|c|c|c|}
\hline \multirow[b]{2}{*}{ Skill } & \multirow[b]{2}{*}{ Groups } & \multirow[b]{2}{*}{ No } & \multirow[b]{2}{*}{ Mean } & \multirow[b]{2}{*}{ SD } & \multicolumn{2}{|c|}{ Paired T- test } \\
\hline & & & & & $T$ & $P$-value \\
\hline \multirow{2}{*}{$\begin{array}{l}\text { Listening for } \\
\text { Specific } \\
\text { information }\end{array}$} & Pre & 30 & 1.90 & .88 & \multirow{2}{*}{10.14} & \multirow{2}{*}{.000} \\
\hline & Post & 30 & 3.93 & .83 & & \\
\hline \multirow{2}{*}{$\begin{array}{c}\text { Listening for } \\
\text { Gist }\end{array}$} & Pre & 30 & 1.60 & 1.03 & \multirow{2}{*}{15.21} & \multirow{2}{*}{.000} \\
\hline & Post & 30 & 4.10 & .76 & & \\
\hline \multirow{2}{*}{$\begin{array}{c}\text { Listening for } \\
\text { Details }\end{array}$} & Pre & 30 & 1.90 & .88 & \multirow{2}{*}{10.47} & \multirow{2}{*}{.000} \\
\hline & Post & 30 & 3.97 & .93 & & \\
\hline \multirow{2}{*}{ Total } & Pre & 30 & 5.40 & 2.32 & \multirow{2}{*}{15.05} & \multirow{2}{*}{.000} \\
\hline & Post & 30 & 12.000 & 2.05 & & \\
\hline
\end{tabular}

Results in Table three show that the students mean score of each listening sub-skill in the post-test were increased (3.93, $4.10,3.97)$. These results indicate that the higher mean score is for the post administration of the experimental group's post-test. Therefore, the SRS training was effective in improving each listening sub-skill. All t-test results were significant at $<0.001^{*}$ level which reflects the significant differences between the mean scores of the experimental group pre-and post-test favoring the post-application.

A closer look to the total score, table six reports that the students' mean score. In the overall listening test in the experimental group was (5.40). On the other hand, the experimental group's overall mean score in the post listening test was (12.00).

The increase in the mean score of the experimental group in the post-test implies that the students' level in overall listening test have been developed due to the training. The paired T-test results indicate that the differences between the mean score of the experimental group students in the pre-and post- listening test was statistically significant at $<0.001^{*}$ level in favor of the 
post application which, in turn, indicates the effectiveness of the SRS-based training in the students' listening skills.

Table (4) :T-test of the experimental group on the pre-post administration of the speaking test:

\begin{tabular}{|c|c|c|c|c|c|c|}
\hline \multirow[b]{2}{*}{ Skill } & \multirow[b]{2}{*}{ Groups } & \multirow[b]{2}{*}{ No } & \multirow[b]{2}{*}{ Mean } & \multirow[b]{2}{*}{ SD } & \multicolumn{2}{|c|}{ Paired T- test } \\
\hline & & & & & $\mathbf{T}$ & $\begin{array}{c}P \text { - } \\
\text { value }\end{array}$ \\
\hline \multirow{2}{*}{ pronunciation } & Pre & 30 & 4.40 & 1.50 & \multirow{2}{*}{14.45} & \multirow{2}{*}{.001} \\
\hline & Post & 30 & 6.73 & 1.28 & & \\
\hline \multirow[b]{2}{*}{ fluency } & Pre & 30 & 4.60 & 1.35 & \multirow[b]{2}{*}{14.45} & \multirow{2}{*}{.001} \\
\hline & Post & 30 & 6.93 & 1.20 & & \\
\hline \multirow[t]{2}{*}{ vocabulary } & Pre & 30 & 4.53 & 1.46 & \multirow{2}{*}{13.68} & \multirow{2}{*}{.001} \\
\hline & Post & 30 & 6.60 & 1.22 & & \\
\hline \multirow[b]{2}{*}{ Accuracy } & Pre & 30 & 4.57 & 1.63 & \multirow{2}{*}{11.60} & \multirow{2}{*}{.001} \\
\hline & Post & 30 & 6.53 & 1.38 & & \\
\hline \multirow{2}{*}{ Comprehensibility } & Pre & 30 & 4.50 & 1.70 & \multirow{2}{*}{11.99} & \\
\hline & Post & 30 & 6.60 & 1.33 & & \\
\hline \multirow{2}{*}{ Total } & Pre & 30 & 22.60 & 6.42 & \multirow{2}{*}{21.54} & \multirow{2}{*}{.001} \\
\hline & Post & 30 & 33.40 & 5.12 & & \\
\hline
\end{tabular}

Results in Table four show that the students mean score of each speaking sub-skill in the post-test were increased 6.73, $6.93,6.60,6.53,6.60)$. These results indicate that the higher mean score is for the post administration of the experimental group's post-test. Therefore, the SRS training was effective in improving each speaking sub-skill. All T-test results were significant at $<0.001^{*}$ level which reflects the significant differences between the mean scores of the experimental group pre and post-test favoring the post-application.

This development can be due to the influence of the student response system based program on training students This resorts to the extra practice and engagement during the implementation of SRS. It is also because students realized that 
they would participate using their clickers in voting for the right answer. By this way, they were all totally engaged in the listening process to give the right answer as the students' participation are presented on the screen instantly. So, this development led to accept the hypothesis.

\section{conclusion}

The proposed SRS-based training resulted in improving EFL listening and speaking skills. The researcher noticed the following points about the experimental group:

- Students the SRS groups experienced significant positive changes in listening skills from mean pre-test score to mean post-test score. The average listening skills score for students who were exposed to the traditional lecture method in EFL classroom decreased at the post-test. Increased students' listening ability in English indicates that interactive approaches such as SRS is capable of fostering EFL learners' listening skills

- Students' attention was continued because they were actively involved in the learning process and anticipating their teacher's questions. However, the instructional process in the control group followed a traditional way of teaching in which the teacher is the center of the learning process not the students.

- students in SRS classroom settings were the center of the learning environments, so they were provided with sufficient chances for more talk time than they would have had in the traditional classroom.

- As developing learners' speaking abilities requires sufficient time to practice the language use in real-life situations, rather than exposing them to repetition, memorization and drills. The series of interactive activities the intervention groups of this study engaged in, facilitated their access to support from peers and unhindered interaction. As the students became involved in the negotiation process, communication was probably 
maintained and sustained among them, as well as between the teacher and the pupils.

- the students in the control group were not motivated and active and they only care about the exams' score. Moreover, there was no interaction between the students and the researcher. The teacher gave them the main idea to talk about and they just follow their teacher's instructions without adding or thinking about any creative ideas.

\section{Recommendations}

Based on the previous results, the present study recommends the following:

1. listening and speaking skills should receive appropriate attention in order to be developed especially at secondary school and university years.

2. student response system should be integrated in the curriculum for students and in the classroom teaching.

3. Not only listening and speaking skills should be tackled, but also evaluating it regularly in order to identify students' needs and problems.

\section{Suggestions for further research}

- Investigating the effect of the student response system based program on English language learning among university students and on other language skills such as listening, writing and reading among college students.

- Investigating the effect of using other strategies on developing students' listening and speaking skills.

\section{References}

Abdelrahman(2013) Effect of Using Internet Tools Enhancing EFL Students' Speaking Skill. PhD, Yarmouk University, Jordan.

Agbatogun, A. (2012). Enhancing Second Language Skills Development Using Students Response System.p1-8. 
Agbatogun, Alaba Olaoluwakotansibe. Journal of Information Technology Education. 2012, Vol. 11, p249267. $19 \mathrm{p}$

Arono. (2014). Improving students' listening skill through interactive multimedia in Indonesia. Journal of Language Teaching and Research, 5(1): 63-69.

Bergtrom, G. (2006). Clicker sets as learning objects. Interdisciplinary Journal of Knowledge and Learning Objects, 2, 105-110. Retrieved from http://www.ijello.org/Volume 2/v2p105-110Bergtrom.pdf

Brookhart,S., Long, B., \& Moss, C. (2008, November). Formative assessment that empowers. Educational Leadership, 66(3), 52-57.

Broughton, G., Brumfit, C., Flavell, R., Hill, P. \& Pincas, A. (1978). Teaching English as a Foreign Language. London: Routledge \& Kegan Paul

Brown, H.D. (1994). Principles of language learning and teaching. Englewood Cliffs, NJ: Prentice Hall Regents.

Brown, H.D. (2001). Teaching by Principles, An Interactive Approach to Language Pedagogy, New York: Addison Wesley Longman.

Brown 2003. Language Assessment: Principles and Classroom Practice. San Francisco: Longman

Butler, D. L., and P. H. Winne. 1995. Feedback and self-regulated learning: A theoretical synthesis. Review of Educational Research 65 (3): 245-281.

Bygate, M.(1987). Speaking. Oxford: Oxford University Press.

Byrne, D. (1986). Teaching Oral English. Cambridge: Cambridge University Press.

Cain, J., \& Robinson, E. (2008). A primer on audience response systems: Current applications and future considerations. American Journal of Pharmaceutical Education, 72, 1- 6.

Crouch, C. H., \& Mazur, E. (2001). Peer instruction: Ten years of experience and results. American Jour-nal of Physics, 69, 970 - 977. 
Crystal, D. (1977). Advanced Conversational English. London: Longman.

Devine, T. G. (1982). Teaching study skills. Boston, MA: Allyn \& Bacon.

D'Inverno, R., Davis, H., \& White, S. (2003). Using a personal response system for promoting student interaction. Teaching Mathematics and Its Applications, 22(4), 163-169

Feyten, C. M. 1991. 'The power of listening ability: An overlooked dimension in language acquisition'. Modern Language Journal 75/2: 173-80.

Gladney E S 1980 Elemental concentrations in NBS biological logical and environmental standard reference materials. Anal. Chim. Acta 118, 385-396.

Hall, C. W. \& Swart, W. W. (2007). Utilising wireless polling devices to enhance classroom participation. Journal of Systemics, Cybernetics and Informatics, 5(3), 36-39.

Hancock, T. M. (2010). Use of audience response systems for summative assessment in large class. Aus-tralasian Journal of Educational Technology, 26(2), 226-237.

Hedge, T. (2000). Teaching and Learning in the Language Classroom. Oxford: Oxford University Press.

Heaton, J. B. (1988). Writing English language tests. Longman. Hoffman, C., \& Goodwin, S. (2006). A clicker for your thought: Technology for active learning. New Li-brary World, 107(9/10), $422-433$.

Hyslop, N. , \& Tone, B. (1988). Listening: Are we teaching it, and if so, how? ERIC Digest, 3. (ERIC Document No.295132), ERIC Clearinghouse on Reading and Communication Skills, Bloomington, IN.

Johnson, M., \& Robson, D. (2008). Clickers, student engagement and performance in an introductory eco-nomics course: A cautionary tale. CHEER Virtual Edition, 20, 4-12.

Johnson, K. \& Lillis, C. (2010). Clickers in the laboratory: Student thoughts and views. Interdisciplinary Journal of Information, Knowledge, and Management, 5, 139-151. 
Kayi, H. 2006. Teaching Speaking: Activities to Promote in Second Language. TSL Journal. Vol. 12. Accessed from: http:/itslj.org.article/kayiteaching.htm.

Klein, K., \& Kientz, M. (2013). A model for successful use of student response systems. Nursing education perspectives, 34(5), 334-338.

Kuh, G. D., K. B. Douglas, J. P. Lund, and J. Ramin-Gyurnek. 1994. Student learning outside the classroom: Transcending artificial boundaries. ASHE-ERIC Higher Education Report No. 8. Washington, DC: George Washington University, School of Education and Human Development. http://www. ericdigests.org/1996-4/student.htm (accessed September 29, 2008). Archived at http://www.webcitation.org/5bCv Wc62g.

Kulhavy, R. W., and W. A. Stock. 1989. Feedback and written instruction: The place of response certitude. Educational Psychology Review 1:279-308.

Larson, L. (2009, May). Reader response meets new literacies: Empowering readers in online learning communities. Reading Teacher, 62(8), 638-648.

Lea, B. (2008). Clickers adoption in a small class setting. Decision Line, 39, 7-11. Retrieved from http://www. Decision sciences.org/decisionline/Vol39/39 4/dsi-dl39 4class.pdf

Liu, W. C., \& Stengel, D. N. (2011). Improving student retention and performance in quantitative courses using clickers. International Journal for Technology in Mathematics Education, 18(1), 51-58.

Locke, E. A., and G. P. Latham. 1990. A theory of goal setting and task performance. Englewood Cliffs, NJ: Prentice Hall

Marlow, D. W., Wash, P. D., Chapman, J. M., \& Dale, T. M. (2009). Electric engagement: The use of classroom response technology in four disciplines. Currents in Teaching and Learning, 2(1), 17-27. Retrieved from http://www. worcester.edu/Currents/Archives/Volume 2 Number 1/C URRENTSV2N1MarlowetalP17.pdf 
Martyn, M. (2007). Clickers in the classroom: An active learning approach. Educause Quarterly, 2, 71-74.

Mintzes, J. J., \& Leonard, W. H. (2006). Handbook of college science teaching. Arlington, VA: NSTA Press

Morley, Joan, (2001), "Aural comprehension instruction: principles and practices", in Marianne Celce-Murcia (ed.), Teaching English as a Second orForeign Language, 3rd Edition, Boston: Heinle \& Heinle.

Nation, P. (1991). Fluency Improvement in a Second Language. RELC Journal, vol. 22: 1, 8494.

O"Malley, J.M. \& Valdez Pierce, L. (1996). Authentic Assessment for English Language Learners. MA: Addison-Wesley.

Oxford, R. L. 1990. Language learning Strategies, what every teacher should know. London: Heinle \& Heinle

Peterson, P., (1991) "A Synthesis of methods for interactive listening", in M. elce-Murcia, (ed), Teaching English as a Second or Foriegn Language, $2^{\text {nd }}$ edition (ppp.106-122), New York: Newbury House

Richards, J. 2008. Teaching Listening and Speaking from Theory to Practice. Cambridge: Cambridge University Press.

Rost, M. (1994) Introducing Listening. London: Penguin

Syakur. 1987. Language Testing and Evaluation. Surakarta: Sebelas Maret University Press

Scarcella, R. C., \& Oxford, R. L. (1992). The tapestry of language learning: The individual in the communicative classroom. Boston, MA: Heinle \& Heinle.

Seidlhofer, B. (2005) 'Key concepts in ELT: English as a lingua franca'. ELT Journal, 59(4), 339 - 341.

Shaw, A. (2009).What is 21st century education? 21st Century Schools, retrieved from http:www.21stcenturyschools. com/What_is_21st_Century-Education. Htm

Simpson, V., \& Oliver, M. (2007). Electronic voting systems for lectures then and now: A comparison of research and practice. Australasian Journal of Educational Technology, 23(2), 187-208. 
Suryani, I., Hizwari, S., Islam, M. A. \& Desa, H. (2012). Using weblog in learning English and encouraging adaptation among international students in Perlis. Higher Education Studies, 2(1), 27-31.

Torrico, F. (2015). Drama techniques to enhance speaking skills and motivation in EFL secondary classroom. (Trabajo Fin de Máster). Universidad Complutense de Madrid, E-Prints Complutense

Thornbury, S. (2005). How to Teach Speaking. New York: Longman.

Thomas, C.N., Pinter, E.B., Carlisle, A., Goran, L. (2015). Student response systems: Learning and engagement in pre-service teacher education. Journal of Special Education Technology, 30(4), 223-237Truesdale, S. P. (1990). Whole-body listening: Developing active auditory skills. Language, Speech, and Hearing Services in Schools, 21, 183-184.

Vandergrift, L. (1999). Facilitating second language listening comprehension: acquiring successful strategies. ELT Journal, 53, 168-176.

Wolvin, A. D., \& Coakley, C. G. (1988). Listening (3rd ed.). Dubuque, IA: Wm. C. Brown

Wood, W. B. (2004). Clickers: A teaching gimmick that works. Developmental Cell, 6(6), 796-798. 
